\title{
Managerial ties, strategic initiatives, and firm performance in Central Asia and the Caucasus
}

\author{
Kiran M. Ismail • David L. Ford, Jr. • \\ Qingsheng Wu • Mike W. Peng
}

Published online: 4 September 2012

(C) Springer Science+Business Media, LLC 2012

\begin{abstract}
Managerial ties are an area commanding managers' attention in emerging economies. However, no previous study has drawn on cross-country data to address a crucial question: Are more developed market-supporting institutions associated with less use of managerial ties in emerging economies? Further, to strive for better performance, firms also need to develop market-based strategic initiatives. How do these initiatives impact performance? What role do managerial ties play in the relationship? Addressing these questions, this article extends research on managerial ties in emerging economies to an underexplored region-Central Asia and the Caucasus.
\end{abstract}

Keywords Managerial ties $\cdot$ Strategic initiatives $\cdot$ Central Asia $\cdot$ The Caucasus

Managerial ties are an important vehicle to facilitate the management of favors (Puffer, McCarthy, Jaeger, \& Dunlap, 2013). In the absence of formal marketsupporting institutions, managerial ties - ties with managers at other firms and ties

K. M. Ismail

Department of Management, Bent Hall 423, St. John's University, The Peter J. Tobin College

of Business, 8000 Utopia Parkway, Queens, NY 11439, USA

e-mail: ismailk@stjohns.edu

D. L. Ford, Jr. • M. W. Peng

Jindal School of Management, University of Texas at Dallas, P.O. Box 830688, SM 43, Richardson, TX 75083, USA

D. L. Ford, Jr.

e-mail:mzad@utdallas.edu

M. W. Peng

e-mail: apjmpeng@gmail.com

Q. Wu $(\bowtie)$

Antai College of Economics and Management, Shanghai Jiao Tong University, Shanghai 200052,

China

e-mail: qswu@sjtu.edu.cn 
with government officials - have long argued to be an area commanding managers' attention in emerging economies (Peng \& Heath, 1996; Puffer et al., 2013). Both forms of ties have been documented to impact firm performance in emerging economies such as China (Li, Poppo, \& Zhou, 2008; Peng \& Luo, 2000), Ghana (Acquaah, 2007), Hungary (Danis, Chiaburu, \& Lyles, 2010), Russia (Puffer \& McCarthy, 2007), and South Korea (Kwon, 2011). Scholars argue that the more market-supporting institutions are developed, the less need managers may feel about devoting time and resources to cultivate managerial ties (Danis et al., 2010; Peng, 2003; Zhou, Poppo, \& Yang, 2008). While these studies have used single country data, the theoretical claim for the importance of managerial ties has yet to be tested with cross-country (as opposed to single country) data. Further, to strive for better performance, firms also need to develop capabilities in market-based strategic initiatives, such as developing new product lines and introducing new technologies (Kriauciunas \& Kale, 2006; Peng \& Luo, 2000; Zhou \& Li, 2007).

Thus, questions left unexplored include: (1) Are more developed marketsupporting institutions associated with less use of managerial ties in emerging economies? (2) How do firms' strategic initiatives impact firm performance? (3) Are firms that can combine excellent managerial ties with strong strategic initiatives more likely to attain better performance compared to firms that do not? Addressing these questions, this article extends research on managerial ties and strategic initiatives in emerging economies to a region that has been largely ignored by researchers - Central Asia and the Caucasus.

Most research on Central and Eastern Europe and the former Soviet Union has focused on the European parts (Gelbuda, Meyer, \& Delios, 2008; Meyer \& Peng, 2005), and most research on Asia deals with East, Southeast, and South Asia (Bruton $\&$ Lau, 2008). There is very little published research on Central Asia and the Caucasus - or Central Eurasia as the region is often referred to (see Ardichvili \& Gasparishvili, 2003; Ford \& Ismail, 2006; Ismail \& Ford, 2010 for exceptions). Thus, extending research to this region serves against the uncritical acceptance of empirical results elsewhere, and "helps determine the generalizability of findings from elsewhere" (Acquaah, 2007: 1236).

This study contributes to the literature in two ways. First, our study, positioned as part of the next generation of research on managerial ties and strategic initiatives, addresses previously unexplored questions on (1) the direct relationship between institutional development and managerial ties and (2) the moderating relationship between managerial ties on the one hand and strategic initiatives and firm performance on the other hand. Second, we investigate these important questions in a region that has been largely ignored by researchers. Overall, our research framework is shown in Fig. 1.

\section{Institutional efficiency and managerial ties}

In emerging economies, inefficient formal market-supporting institutions necessitate a strategy centered on developing managerial ties (Estrin \& Prevezer, 2011; Peng \& Heath, 1996). McEvily and Zaheer (1999) suggested that participation in professional associations, whose members consist of managers at other firms, can help firms gain access to resources and information. In a similar vein, we suggest that inefficient 


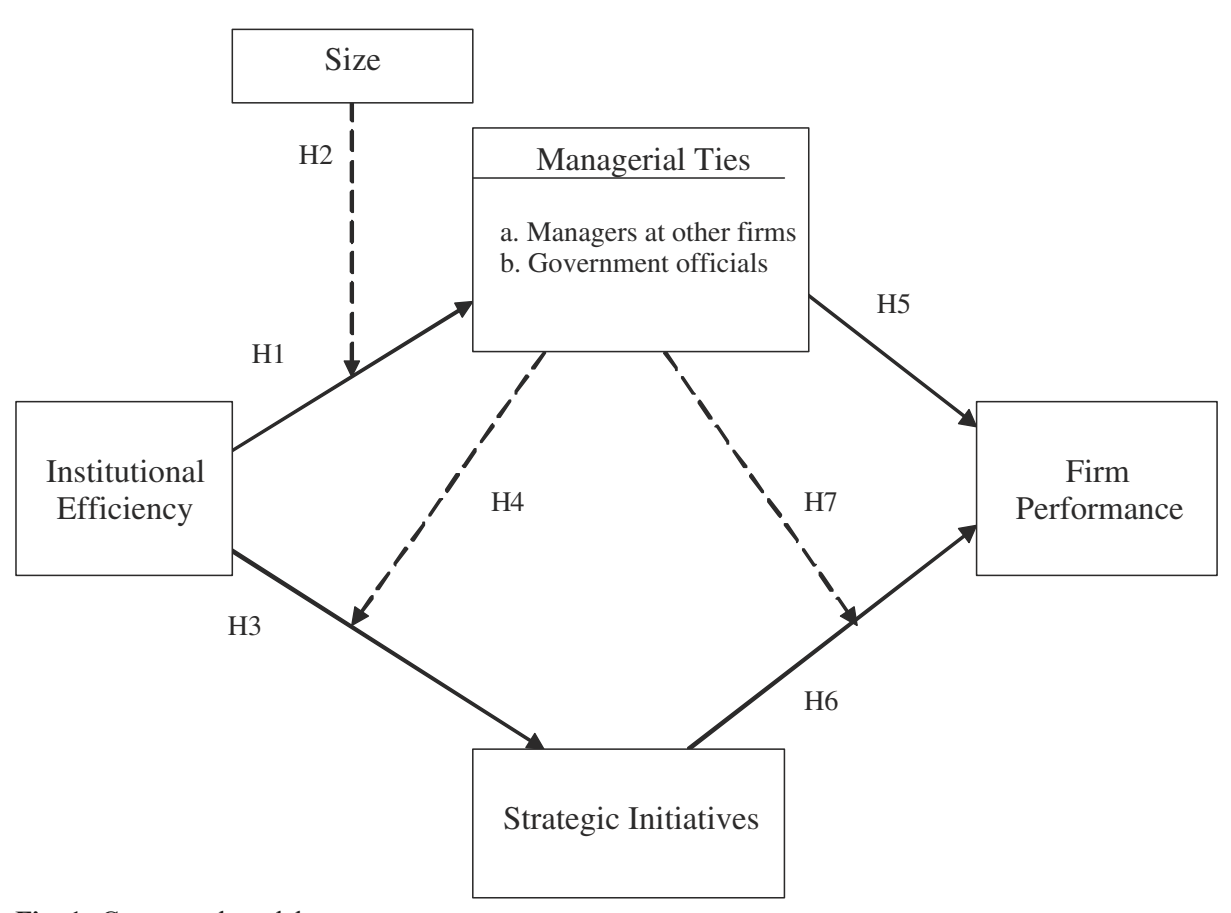

Fig. 1 Conceptual model

institutional conditions characterized by policy uncertainty and inefficient legal systems drive firms to seek (1) ties with managers at other firms and (2) ties with government officials in order to get things done.

Hypothesis 1 The less institutionally efficient the environment, the more firms seek to build managerial ties (a) with managers at other firms and (b) with government officials.

One important difference in the propensity to engage in managerial ties may be firm size (Shinkle \& Kriauciunas, 2010). Larger firms may have greater resources to absorb environmental risks. Smaller firms may be more vulnerable to inefficient institutions. Thus, it may be more critical for smaller firms to form managerial ties in order to deal with the market imperfections (Peng \& Luo, 2000). However, when market-supporting institutions become more efficient, smaller firms may not view spending their limited resources in building ties to others as beneficial. In other words, the relationship between institutional efficiency and managerial ties may be moderated by firm size.

Hypothesis 2a Smaller firms in institutionally inefficient environments will more frequently engage in building managerial ties with managers at other firms than larger firms.

Hypothesis 2b Smaller firms in institutionally inefficient environments will spend more time building managerial ties with government officials than larger firms. 


\section{Institutional efficiency and strategic initiatives}

Well-developed market-supporting institutions may reduce the need for firms to spend time and resources on managerial ties (Danis et al., 2010; Peng, 2003; Zhou \& Peng, 2010). Firms in institutionally developed environments can invest more time and resources on productive strategic initiatives (Kriauciunas \& Kale, 2006). Although in the Central Eurasian region, the establishment of democratic political systems and market economies has been slow (Blank, 2004), certain countries (such as Georgia) have made better progress than others. Acknowledging the variations in institutional development in the region, we propose that firms in institutionally developed environments can invest more time and resources on taking advantage of market opportunities brought forth by market liberalization, and undertake productive strategic initiatives. In addition, we argue that the relationship between institutional efficiency and strategic initiatives may be moderated by managerial ties. Such ties can provide firms with access to resources to better deal with the uncertainties and challenges, and successfully undertake strategic initiatives (Peng \& Heath, 1996).

Hypothesis 3 The more institutionally efficient the environment, the higher the level of strategic initiatives.

Hypothesis 4 The relationship between institutional efficiency and strategic initiatives will be moderated by managerial ties such that the positive relationship between institutional efficiency and the level of strategic initiatives will be more salient for firms with managerial ties (a) with managers at other firms and (b) with government officials than for firms without such ties.

\section{Impact on firm performance}

In terms of managerial ties' impact on firm performance, according to Peng and Heath, "in a volatile and uncertain environment, networks stabilize economic activities by having members engage in reciprocal, preferential, and mutually supportive action . . . Networks provide flexibility of resource allocation in an environment where needed factor mobility is severely constrained" (1996: 514). In an underexplored context-Central Asia and the Caucasus-our H5 essentially replicates research of this claim elsewhere (Acquaah, 2007; Kwon, 2011; Peng \& Luo, 2000).

Hypothesis 5 Managerial ties (a) with managers at other firms and (b) with government officials will be positively associated with firm performance.

Further, in an increasingly market-driven environment, the impact of strategic initiatives aimed at boosting firms' competitive advantage is straightforward (Wu \& Chen, 2012; Xu, Huang, \& Gao, 2012; Zhou \& Li, 2007). From a resource-based standpoint, firms able to embark on strategic initiatives possess valuable, rare, and hard-to-imitate capabilities that may differentiate them from those unable to do so (Barney, 1991). 
Hypothesis 6 The level of strategic initiatives undertaken by firms will be positively associated with firm performance.

Our last hypothesis integrates previous work by considering how managerial ties moderate the relationship between strategic initiatives and firm performance. Given the institutional upheaval in Central Asia and the Caucasus, managerial ties may facilitate the successful implementation of strategic initiatives (Roth \& Kostova, 2003) as well as remove some of the market uncertainties and help ensure successful attainment of the goals of strategic initiatives. Thus:

Hypothesis 7 The relationship between the level of strategic initiatives and firm performance will be moderated by managerial ties such that the positive relationships between strategic initiatives and firm performance will be more salient for firms with managerial ties (a) with managers at other firms and (b) with government officials than for firms without such ties.

\section{Methodology}

Sample

We draw on archival data from two World Bank sources. ${ }^{1}$ The first source is the World Bank's Business Environment and Enterprise Performance Survey (BEEPS) conducted during 2001-2002. ${ }^{2}$ BEEPS is a firm-level survey of more than 6,000 firms in 26 transition countries. The data were collected through interviews of top managers. Our dependent and control variables were obtained from this source.

To minimize problems associated with common method variance, we used a different database for out independent variable measures. The second source is the World Bank's Governance Indicators (Kaufmann, Kraay, \& Mastruzzi, 2005). This dataset measures various dimensions of institutional effectiveness, and covers 209 countries for the years 1996, 1998, 2000, 2002, and 2004. We use four dimensions from the 2002 indicators to measure institutional efficiency. ${ }^{3}$

Our sample from BEEPS was based on two criteria: (1) firm age and (2) belonging to the Central Asia and the Caucasus region (as opposed to Central and Eastern Europe or the Baltics). The final sample was composed of 1,214 firms in seven countries: Armenia (153), Azerbaijan (140), Georgia (157), Kazakhstan (214), Kyrgyzstan (158), Tajikistan (159), and Uzbekistan (233). ${ }^{4}$

\footnotetext{
${ }^{1}$ One of the authors has conducted numerous interviews with managers in Central Asia and the Caucasus and worked with them. Our selection of the measures has been driven in part by such experience of direct interaction with managers.

2 Accessed at http://econ.worldbank.org.

3 The selected dimensions corresponded most closely to the perceptual measures of governance included in BEEPS, namely, governmental efficiency, regulatory efficiency, legal system efficiency, and corruption.

${ }^{4}$ One Central Asian country, Turkmenistan, missing due to not being included in the BEEPS survey.
} 
Variables

Institutional efficiency This was represented as a composite measure of the country values from the Governance Indicators dataset for each of the following dimensions: (1) regulatory efficiency, (2) governmental efficiency, (3) legal system efficiency, and (4) corruption. The standardized scale ranged from -1.41 to -.50 , and Cronbach's alpha was .886.

Managerial ties In the spirit of Peng and Luo (2000), we used two dummy variable measures from the BEEPS dataset to capture managerial ties with (1) managers at other firms and (2) government officials. Ties with managers at other firms (TIESMGR) were captured by membership in a professional business association or chamber of commerce $(0=$ No, $1=$ Yes $)$. In the spirit of Danis et al. (2010), ties with government officials (TIESGOV) were captured by the percentage of senior management's time that was spent in dealing and networking with government officials.

Strategic initiatives Firms reported whether they undertook each of the following six initiatives within the past three years: (1) development of a new product line, (2) upgrading of an existing product line, (3) introducing new technology, (4) opening a new plant, (5) obtaining a new licensing agreement, and (6) obtaining a new quality accreditation. The measure was a frequency variable, with $0=$ firm did not undertake any of the initiatives, 1 = one initiative, 2 = two initiatives, and so forth.

Firm performance Firms reported the gross profit margin by which their sales price exceeded their operating costs (i.e., the cost material inputs plus wage costs but not overheads and depreciation) for their main product/service line in the domestic market.

Control variables We included four control variables. (1) Ownership was coded as a dummy variable, with $0=$ "private firm" and $1=$ "state-owned firm." (2) Firm size was included as a categorical variable with three levels whose values were the midpoints of the size ranges and representing small, medium, and large firms. (3) Firm age was constructed as the number of years since the firm's founding. For both firm size and firm age, natural logarithms of the variables were used to correct for skewness. (4) Industry type was coded as a dummy variable, with $0=$ "service firm," and 1 = "manufacturing firm" (Peng \& Luo, 2000).

\section{Results}

Table 1 presents descriptive statistics. Tables 2 and 3 examine managerial ties as a response to institutional inefficiency, with firm size as a potential moderator. Model 3 in Table 2 indicates that managerial ties with managers at other firms are significantly and negatively correlated with institutional efficiency $(p<.001)$, thereby supporting H1a. However, Model 3 in Table 3 indicates that the relationship between institutional efficiency and managerial ties with government officials is not significant. Thus, H1b is not supported. 


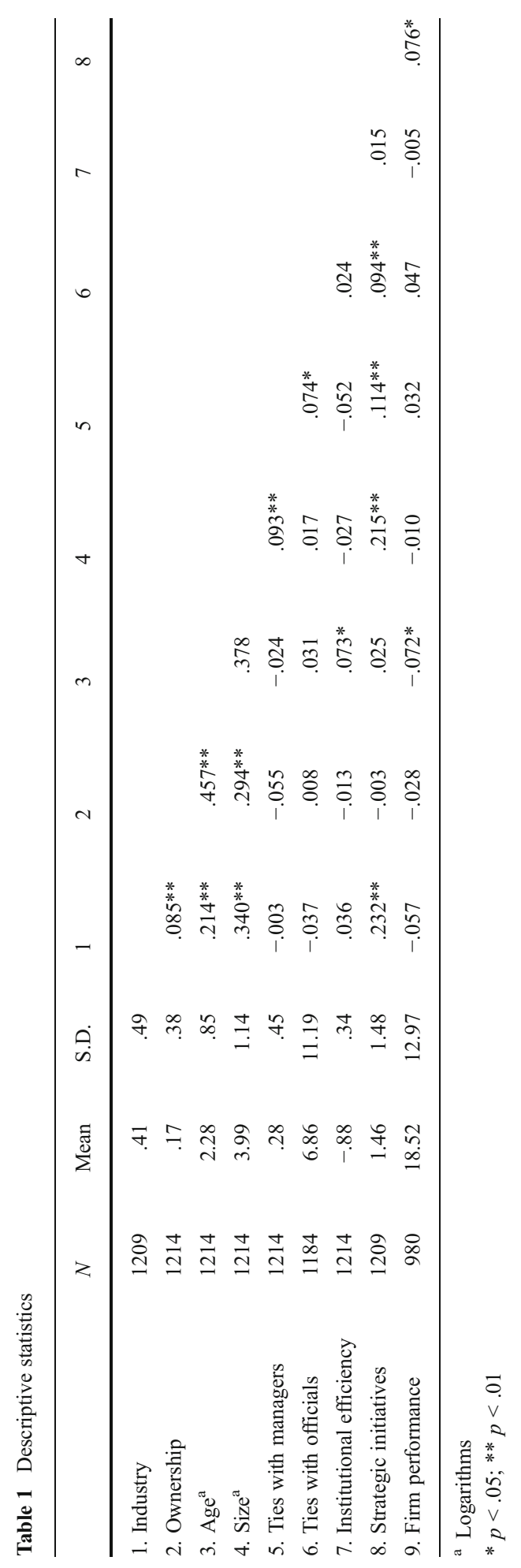


Table 2 Binary logistic regression models for ties with managers at other firms as dependent variable

${ }^{a}$ Logarithms

$\dagger p<.1$

$* p<.05$

$* * p<.01$

$* * * p<.001$
Model 1 Model 2 Model 3

Controls

Industry

Ownership

$\mathrm{Age}^{\mathrm{a}}$

$\begin{array}{ccc}.005 & .012 & -.133 \\ -.353 \dagger & -.375 \dagger & -.484 * *\end{array}$

Independent variable

Institutional efficiency (H1a)

$\begin{array}{lll}.005 & .020 & -.099\end{array}$

Moderator variable

Size $^{\text {a }}$

$1.040^{* * *}$

Interaction term

Institutional efficiency $\times$ Size $^{\mathrm{a}}$

$875^{* * *}$

(H2a)

Cox and Snell $R^{2}$

$.003 \quad .006$

.042

$\mathrm{H} 2 \mathrm{a}$ and $\mathrm{H} 2 \mathrm{~b}$ investigate the interaction between institutional efficiency and firm size. Model 3 in Table 2 indicates that firm size is a significant predictor of ties with managers at other firms $(p<.001)$, along with institutional efficiency, and has a significant moderating effect $(p<.001)$. Thus, H2a is supported. Model 3 in Table 3 does not find this relationship for ties with government officials, thus not supporting $\mathrm{H} 2 \mathrm{~b}$.

To evaluate the moderating effect proposed by H2a, the interaction effect is plotted in Fig. 2. It shows that smaller firms are more likely than larger firms to build managerial ties when institutional efficiency is low. Results from both Table 3 and Fig. 2 combine to support $\mathrm{H} 2$ a that the negative relationship between institutional efficiency and managerial ties is more salient for smaller firms.

Table 4 reports results for $\mathrm{H} 3, \mathrm{H} 4 \mathrm{a}$, and $\mathrm{H} 4 \mathrm{~b}$. Model 2 in Table 4 indicates a nonsignificant (although positive) relationship between institutional efficiency and

Table 3 OLS models for ties with government officials as dependent variable

${ }^{a}$ Logarithms

\begin{tabular}{|c|c|c|c|}
\hline & Model 1 & Model 2 & Model 3 \\
\hline \multicolumn{4}{|l|}{ Controls } \\
\hline Industry & -1.046 & -1.054 & -1.145 \\
\hline Ownership & -.285 & -.241 & -.293 \\
\hline $\operatorname{Age}^{\mathrm{a}}$ & .600 & .570 & .456 \\
\hline \multicolumn{4}{|l|}{ Independent variable } \\
\hline Institutional efficiency (H1b) & & .749 & -3.828 \\
\hline \multicolumn{4}{|l|}{ Moderator variable } \\
\hline $\operatorname{Size}^{\mathrm{a}}$ & & & 1.256 \\
\hline \multicolumn{4}{|l|}{ Interaction term } \\
\hline $\begin{array}{l}\text { Institutional efficiency } \times \text { Size }^{a} \\
(\mathrm{H} 2 \mathrm{~b})\end{array}$ & & & 1.152 \\
\hline Model F & 1.194 & 1.043 & 1.090 \\
\hline$R^{2}$ & .003 & .004 & .006 \\
\hline
\end{tabular}




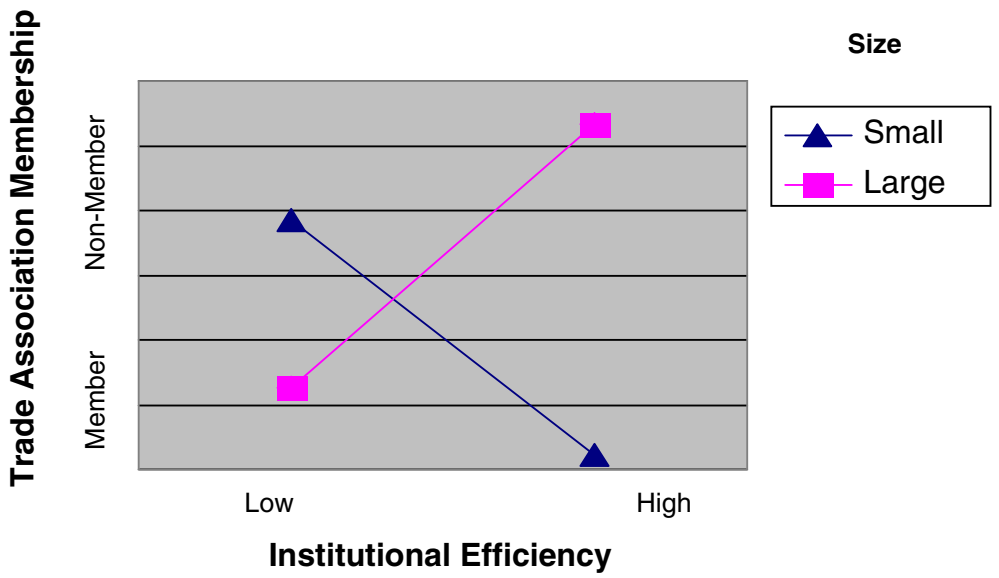

Fig. 2 Moderating effect of firm size on the relationship between institutional efficiency and managerial ties with managers at other firms (trade association membership)

strategic initiatives, and is unable to support H3. Model 3 indicates that ties with managers at other firms and with government officials are both significantly correlated with strategic initiatives $(p<.001)$. Model 4 reports that ties with government officials positively moderates the relationship between institutional efficiency and strategic initiatives $(p<.05)$, supporting H4b. Using the plotting procedure described

Table 4 Poisson regression models for strategic initiative as dependant variable

\begin{tabular}{|c|c|c|c|c|}
\hline & Model 1 & Model 2 & Model 3 & Model 4 \\
\hline \multicolumn{5}{|l|}{ Controls } \\
\hline Industry & $.372 * * *$ & $.371 * * *$ & $.401 * * *$ & $.409 * * *$ \\
\hline Ownership & -.111 & -.107 & -.096 & -.091 \\
\hline $\operatorname{Age}^{\mathrm{a}}$ & $-.070^{*}$ & $-.073 *$ & $-.084 *$ & -.085 \\
\hline $\operatorname{Size}^{\mathrm{a}}$ & $.153 * * *$ & $.154 * * *$ & $.150 * * *$ & $.145^{* * *}$ \\
\hline \multicolumn{5}{|l|}{ Independent variables } \\
\hline Institutional efficiency (H3) & & .055 & .065 & -.050 \\
\hline \multicolumn{5}{|l|}{ Moderators } \\
\hline Ties with managers at other firms (TIESMGR) & & & $.196 * * *$ & .247 \\
\hline Ties with government officials (TIESGOV) & & & $.008 * * *$ & $.019 * *$ \\
\hline \multicolumn{5}{|l|}{ Interaction terms } \\
\hline TIESMGR $\times$ Institutional efficiency $(\mathrm{H} 4 \mathrm{a})$ & & & & .059 \\
\hline TIESGOV × Institutional efficiency $(\mathrm{H} 4 \mathrm{~b})$ & & & & $.014 *$ \\
\hline Psuedo $R^{2}$ & .0354 & .0355 & .0456 & .0466 \\
\hline
\end{tabular}

\footnotetext{
${ }^{\text {a Logarithms }}$

${ }^{\dagger} p<.1$

$* p<.05$

$* * p<.01$

$* * * p<.001$
} 
previously, Fig. 3 visually illustrates this finding. On the other hand, ties with managers at other firms do not have such a moderating effect. Thus, H4a is not supported.

Table 5 focuses on firm performance as a dependent variable. Model 3 in Table 5 shows that $\mathrm{H} 5 \mathrm{a}$, on ties with managers at other firms, is not supported. However, Model 3 supports $\mathrm{H} 5 \mathrm{~b}$, on the positive relationship between ties with government officials and firm performance $(p<.05)$, and H6, on the positive relationship between strategic initiatives and firm performance $(p<.01)$. In terms of the moderating hypotheses, Model 3 indicates that ties with government officials have a significant moderating effect on the relationship between strategic initiatives and firm performance $(p<.05)$, thus supporting H7b. Visually, Fig. 4 shows this moderating relationship, albeit only at low levels of strategic initiatives. However, H7a, on the moderating relationship of ties with managers at other firms, is not supported.

\section{Discussion}

This article contributes to the literature (1) by using cross-country data to probe into the relationship among managerial ties, strategic initiatives, and firm performance in emerging economies and (2) by extending this research to a region that has not often been on the radar screen of researchers - Central Asia and the Caucasus. Our results suggest that lower levels of institutional development may increase the frequency with which firms seek to form ties with managers at other firms but not necessarily with government officials. A possible reason for the lack of support for the relationship between institutional efficiency and ties with government officials may be that firms do not view such ties to be valuable, and, instead, rely more on ties with managers at other firms (often through professional associations) as the means to get things done (Puffer et al., 2013). These findings are different from the China findings, which generally point to the greater importance of ties with government officials as opposed to ties with managers at other firms (Peng \& Luo, 2000). But our findings are consistent with the results of a study conducted in Ghana (Acquaah, 2007).

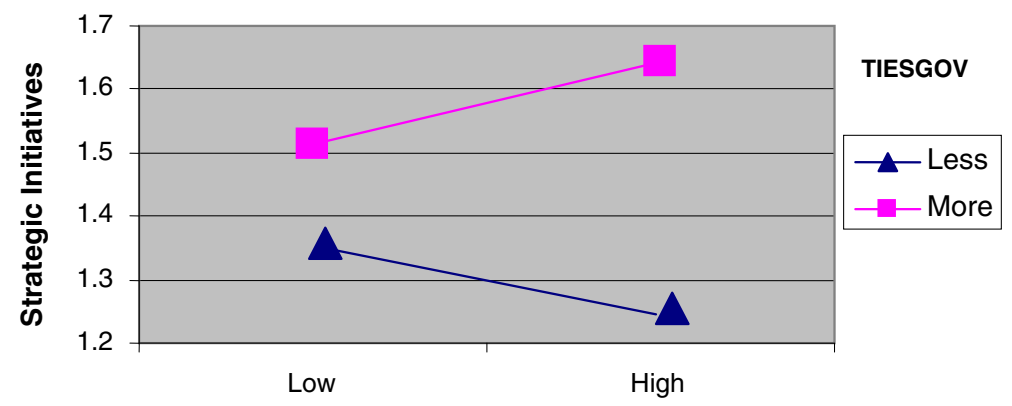

Institutional Efficiency

Fig. 3 Moderating effect of managerial ties with government officials on the relationship between institutional efficiency and strategic initiatives 
Table 5 OLS regression models for firm performance as dependant variable

\begin{tabular}{|c|c|c|c|}
\hline & Model 1 & Model 2 & Model 3 \\
\hline \multicolumn{4}{|l|}{ Controls } \\
\hline Industry & -1.264 & $-1.760 \dagger$ & $-1.790 \dagger$ \\
\hline Ownership & -.452 & -.391 & -.429 \\
\hline Age $^{\mathrm{a}}$ & -.909 & -.806 & -.814 \\
\hline Size $^{\mathrm{a}}$ & .343 & .083 & .102 \\
\hline \multicolumn{4}{|l|}{ Independent variables } \\
\hline Ties with managers at other firms (H5a) & & .301 & .299 \\
\hline Ties with government officials (H5b) & & .043 & $.128 *$ \\
\hline Strategic initiatives (H6) & & $.846^{* * *}$ & $1.257 * *$ \\
\hline \multicolumn{4}{|l|}{ Interaction terms } \\
\hline TIESMGR $\times$ Strategic initiatives $(\mathrm{H} 7 \mathrm{a})$ & & & -.001 \\
\hline TIESGOV $\times$ Strategic initiatives $(\mathrm{H} 7 \mathrm{~b})$ & & & $-.053 *$ \\
\hline Model F & 1.589 & $2.414^{*}$ & $2.407^{*}$ \\
\hline Adjusted $R^{2}$ & .002 & .010 & .013 \\
\hline
\end{tabular}

${ }^{\mathrm{a}}$ Logarithms

${ }^{\dagger} p<.1$

$* p<.05$

$* * p<.01$

$* * * p<.001$

It is interesting to note that within the institutional context of Central Asia and the Caucasus, ties with government officials still play a critical role. These ties not only help firms undertake strategic initiatives when the level of institutional efficiency is low, but they also enable firms to achieve higher performance (Fig. 4). Yet, for firms that are able to undertake high levels of strategic initiatives, spending time and energy in maintaining ties with officials may prove to be a non-value-adding distraction (Chen, Friedman, Yu, \& Sun, 2011; McCarthy, Puffer, Dunlap, \& Jaeger, forthcoming).

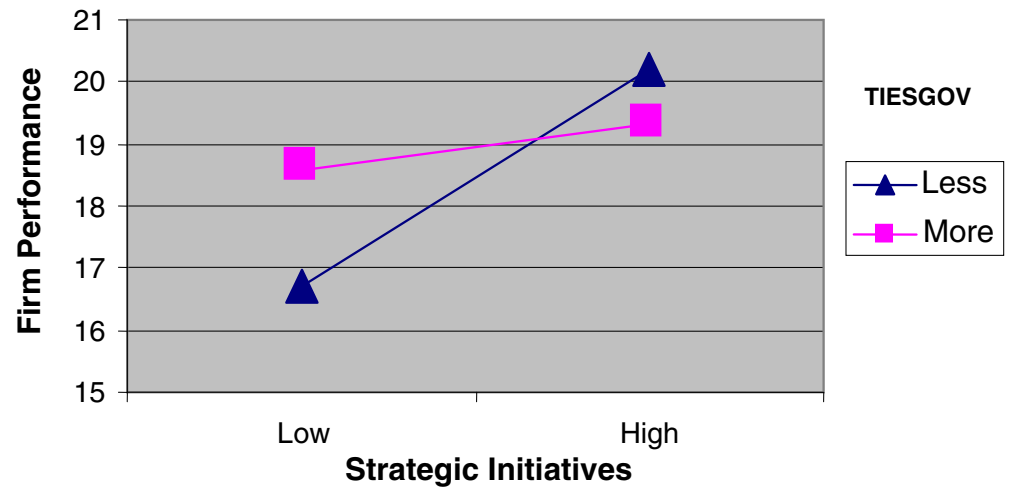

Fig. 4 Moderating effect of managerial ties with government officials on the relationship between strategic initiatives and firm performance 
While some of our findings from Central Asia and the Caucasus converge with those from other emerging economies, some findings seem unique to the region: (1) institutional inefficiency does not appear to impact the decision of firms in our sample to cultivate ties with government officials, and (2) cultivating ties with government officials may be counter-productive for firms that are able to undertake strategic initiatives. To the best of our knowledge, the World Bank data we draw on are the best available cross-country data collected with systematic efforts across the region. However, future research may need to supplement such quantitative data with more qualitative data (Yalcin, 2003) to gain a more in-dept understanding of our findings. Also, how managerial ties and strategic initiatives impact firms' involvement in the "underground" or "informal" sector of the economy in the region remain unexplored but interesting issues for future research.

\section{Conclusion}

In the broader context of managing favors, overall, our results can be interpreted as broadly supportive of the theoretical claim for the importance of managerial ties and for their relationship with institutional development - with some nuances and caveats from Central Asia and the Caucasus. In conclusion, a better understanding of the relationship among managerial ties, strategic initiatives, and firm performance will not only help practitioners improve their effectiveness as they navigate the uncertain course of economic transitions, but also greatly enrich the scholarly literature on favors, strategy, and management in emerging economies.

Acknowledgements An earlier version of this paper was presented at the Academy of Management in Philadelphia and won Best Paper Award Honorable Mention in the International Management Division (August 2007). It was also presented at the Managing Favors Conference at Northeastern University (October 2010) and the Academy of Management in Boston (August 2012). We thank Sheila Puffer and Dan McCarthy for helpful comments. This research was supported by the National Science Foundation of the United States (CAREER SES 0552089), the National Natural Science Foundation of China (project no. 71072060), and the Jindal Chair at UT Dallas. All views are ours and not necessarily those of the sponsors.

\section{References}

Acquaah, M. 2007. Managerial social capital, strategic orientation, and organizational performance in an emerging economy. Strategic Management Journal, 28: 1235-1255.

Ardichvili, A., \& Gasparishvili, A. 2003. Russian and Georgian entrepreneurs and non-entrepreneurs: A study of value differences. Organization Studies, 24: 29-46.

Barney, J. B. 1991. Firm resources and sustained competitive advantage. Journal of Management, 17(1): 99-120.

Blank, S. 2004. Democratic prospects in Central Asia. World Affairs, 166(3): 133-147.

Bruton, G. D., \& Lau, C. M. 2008. Asian management research: Status today and future outlook. Journal of Management Studies, 45(3): 636-659.

Chen, Y., Friedman, R., Yu, E., \& Sun, F. 2011. Examining the positive and negative effects of guanxi practices: A multi-level analysis of guanxi practices and procedural justice perceptions. Asia Pacific Journal of Management, 28(4): 715-735.

Danis, W., Chiaburu, D., \& Lyles, M. 2010. The impact of managerial networking intensity and market-based strategies on firm growth during institutional upheaval: A study of small and 
medium-sized enterprises in a transition economy. Journal of International Business Studies, 41: 287-307.

Estrin, S., \& Prevezer, M. 2011. The role of informal institutions in corporate governance: Brazil, Russia, India, and China compared. Asia Pacific Journal of Management, 28(1): 41-67.

Ford, D. L., \& Ismail, K. M. 2006. Perceptions of effective leadership among Central Eurasian managers: A cultural convergence-divergence examination within a globalization context. Journal of International Management, 12: 158-180.

Gelbuda, M., Meyer, K. E., \& Delios, A. 2008. International business and institutional development in Central and Eastern Europe. Journal of International Management, 14: 1-11.

Ismail, K. M., \& Ford, D. L. 2010. Organizational leadership in Central Asia and the Caucasus: Research considerations and directions. Asia Pacific Journal of Management, 27(2): 321-340.

Kaufmann, D., Kraay, A., \& Mastruzzi, M. 2005. Governance matters IV: Governance indicators for 1996-2004. www.worldbank.org/wbi/governance/pdf/govmatters_IV_main.pdf, Accessed Sept. 15.

Kriauciunas, A., \& Kale, P. 2006. The impact of socialist imprinting and search of resource change: A study of firms in Lithuania. Strategic Management Journal, 27: 659-679.

Kwon, Y. 2011. Relationship-specific investments, social capital, and performance: The case of Korean exporter/foreign buyer relations. Asia Pacific Journal of Management, 28(4): 761-773.

Li, J. J., Poppo, L., \& Zhou, K. Z. 2008. Do managerial ties in China always produce value? Competition, uncertainty, and domestic vs. foreign firms. Strategic Management Journal, 29: 383400 .

McCarthy, D. J., Puffer, S. M., Dunlaps, D., \& Jaeger, A. M. Forthcoming. A stakeholder approach to the ethicality of BRIC-firm managers' use of favors. Journal of Business Ethics.

McEvily, B., \& Zaheer, A. 1999. Bridging ties: A source of firm heterogeneity in competitive capabilities. Strategic Management Journal, 20: 1133-1156.

Meyer, K. E., \& Peng, M. W. 2005. Probing theoretically into Central and Eastern Europe: Transactions, resources, and institutions. Journal of International Business Studies, 36(6): 600-621.

Peng, M. W. 2003. Institutional transitions and strategic choices. Academy of Management Review, 28(2): 275-296.

Peng, M. W., \& Heath, P. 1996. The growth of the firm in planned economies in transition: Institutions, organizations, and strategic choice. Academy of Management Review, 21(2): 492-528.

Peng, M. W., \& Luo, Y. 2000. Managerial ties and firm performance in a transition economy: The nature of a micro-macro link. Academy of Management Journal, 43(3): 486-501.

Puffer, S. M., \& McCarthy, D. J. 2007. Can Russia's state-managed, network capitalism be competitive? institutional pull versus institutional push. Journal of World Business, 42: 1-13.

Puffer, S. M., McCarthy, D. J., Jaeger, A. M., \& Dunlap, D. 2013. The use of favors by emerging market managers: Facilitator or inhibitor of international expansion?. Asia Pacific Journal of Management (this issue, doi:10.1007/s10490-012-9299-3).

Roth, K., \& Kostova, T. 2003. Organizational coping with institutional upheaval in transition economies. Journal of World Business, 38(4): 314-330.

Shinkle, G. A., \& Kriauciunas, A. P. 2010. Institutions, size, and age in transition economies: Implications for export growth. Journal of International Business Studies, 41: 267-286.

Wu, J., \& Chen, X. 2012. Leaders' social ties, knowledge acquisition capability, and firm competitive advantage. Asia Pacific Journal of Management, 29(2): 331-350.

Xu, K., Huang, K.-F., \& Gao, S. 2012. The effect of institutional ties on knowledge acquisition in uncertain environments. Asia Pacific Journal of Management, 29(2): 387-408.

Yalcin, S. 2003. Difficulties of conducting field research in the Caucasus and Central Asia. Central Eurasian Studies Review, 2(3): 15-16.

Zhou, J. Q., \& Peng, M. W. 2010. Relational exchanges versus arm's-length transactions during institutional transitions. Asia Pacific Journal of Management, 27(3): 355-370.

Zhou, K. Z., \& Li, C. B. 2007. How does strategic orientation matter in Chinese firms? Asia Pacific Journal of Management, 24(4): 447-466.

Zhou, K. Z., Poppo, L., \& Yang, Z. 2008. Relational ties or customized contracts? An examination of alternative governance choices in China. Journal of International Business Studies, 39: 526-534.

Kiran M. Ismail ( $\mathrm{PhD}$, University of Texas at Dallas) is an assistant professor of management at the Peter J. Tobin College of Business, St. John's University. Her research centers on business, leadership and management concerns in transition economies, and organization behavior and human resource management issues associated with inter- and intra-organizational relationships. 
David L. Ford, Jr. (PhD, University of Wisconsin-Madison) is a professor of organizational behavior at the Jindal School of Management, University of Texas at Dallas. His research interests include crosscultural comparisons of leader effectiveness in developing and emerging economies of Central Eurasia, Africa, and the African Diaspora; job stress and coping in organizations; in-role and extra-role behavior of organizational employees; and team cognition and decision processes.

Qingsheng Wu ( $\mathrm{PhD}$, Shanghai Jiao Tong University) is an associate professor of marketing at the Antai College of Economics and Management, Shanghai Jiao Tong University. His research interests are marketing strategy and new product management.

Mike W. Peng ( $\mathrm{PhD}$, University of Washington) is the Jindal Chair of Global Strategy at the Jindal School of Management, University of Texas at Dallas. His research interests are global strategy, international business, and emerging economies with a focus on the institution-based view. 